УдК 541.138

Л. В. Петренко, ${ }^{1}$ Віктор І. Коробов, ${ }^{1}$ В. Ф. Очков ${ }^{2}$

${ }^{1}$ Дніпропет ровський національний університ ет імені Олеся Гончара, пр. Гагаріна, 72, Дніпропет ровськ 49010, Україна

${ }^{2}$ Національний дослідницький університ ет «Московський енергет ичний інст ит ут », вул. Красноказармена, 14, Москва 111250, Росія

\title{
ВПЛИВ АНІОНІВ СУЛЬФАТНОЇ КИСЛОТИ НА АНОДНУ ПОВЕДІНКУ НІКЕЛЮ
}

У стадіях анодного розчинення і пасивації металів родини Феруму в розчинах сульфатної кислоти можуть приймати участь аніони $\mathrm{HSO}_{4}^{-}$i $\mathrm{SO}_{4}^{2-}$. Зі застосуванням математичного моделювання проаналізовано можливий вплив аніонів сульфатної кислоти на анодну поведінку нікелю в кислих розчинах. Показано, що у випадку адсорбції сульфат-аніонів на поверхні нікелю на анодних поляризаційних залежностях спостерігається зниження максимальних значень струмів. При цьому можливі зміни величини тафелевського нахилу ділянки активного розчинення нікелю і значень потенціалів максимумів струмів. Збільшення максимальних значень анодних струмів буде спостерігатись у разі безпосередньої участі аніонів сульфатної кислоти в стадіях розчинення нікелю або у випадку їх включення до складу осигеновмісних плівок. Експериментально встановлено, що хід анодних поляризаційних залежностей нікелевого

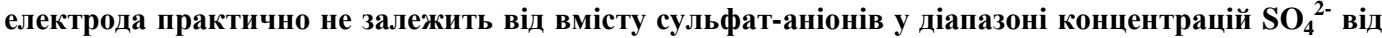
0,2 до 1,2 моль-екв/л (рН = 1,0). Це дає змогу стверджувати, що сульфат-аніони не впливають на загальний механізм анодного розчинення і пасивації нікелю.

Ключові слова: нікель; кисле середовище; анодне розчинення; пасивація; сульфат-аніони; моделювання.

Вступ. У стадіях анодного розчинення і пасивації нікелю в розчинах сульфатної кислоти беруть участь йони $\mathrm{H}^{+}, \mathrm{OH}^{-}$і молекули води [1]. Присутні в цих розчинах аніони сульфатної кислоти $\left(\mathrm{HSO}_{4}{ }^{-} \mathrm{i} \mathrm{SO}_{4}{ }^{2-}\right)$ також можуть приймати участь в анодних процесах.

Стосовно впливу аніонів сульфатної кислоти на анодне розчинення i пасивацію нікелю єдиної думки немає. Так, автори робіт [2; 3] на підставі того, що на анодних поляризаційних кривих нікелевого електрода в розчинах сульфатної кислоти спостерігаються два максимуми анодного струму, на відміну від розчинів хлорної кислоти, де спостерігали лише один максимум, роблять висновок про активуючу дію йонів $\mathrm{SO}_{4}^{2-}$. За їхньою думкою аніони, при потенціалах другого максимуму, адсорбуються на поверхні електрода, витісняють кисень, чим порушують пасивний шар, що був сформований при потенціалах першого максимуму.

Згідно 3 іншими дослідженнями [4; 5], у розчинах $\mathrm{HClO}_{4}$ на анодних поляризаційних залежностях нікелевого електрода спостерігались два максимуми струму, як $\mathrm{i}$ в розчинах $\mathrm{H}_{2} \mathrm{SO}_{4}$. Суттєво не відрізнялись одна від одної $\mathrm{i}$ поляризаційні залежності, одержані в розчинах сульфатної і фосфатної кислот [6; 7] 3 однаковим значенням $\mathrm{pH}$, хоча за своєю активуючою дією сульфат- і фосфатаніони не є рівноцінними.

Висновки щодо участі аніонів сульфатної кислоти в процесах анодного розчинення й пасивації нікелю та інших металів підгрупи Феруму зроблені і в роботах [8; 9]. Підставою для цього були залежності величин анодних струмів від вмісту аніонів сульфатної кислоти в розчинах. Наприклад, авторами роботи [8]

* Correspoding author: Tel.: +380567768253; fax: +380563749841; e-mail address: korvik58@mail.ru

(С) Л. В. Петренко, Віктор І. Коробов, В. Ф. Очков, 2013 
виявлено, що збільшення концентрації $\mathrm{SO}_{4}^{2-}$ приводить до зниження величини струму першого максимуму й до збільшення другого максимуму на i,Е-залежностях нікелевого електрода. На підставі цього стверджується, що сульфат-іони адсорбуються на так званих активних центрах I роду, які виявляють себе при потенціалах першого максимуму, та гальмують розчинення нікелю. При потенціалах другого максимуму поверхневі комплекси з сульфат-іонами стають розчинними, що і приводить до збільшення анодних струмів.

Нарешті, за результатами ряду робіт, аніони сульфатної кислоти практично не впливають на анодне розчинення нікелю як у кислих [10 - 12], так і в лужних [13] розчинах. Зокрема, в [12] зазначається, що розчини сульфатної кислоти, наряду 3 розчинами хлорної кислоти, є сприятливим середовищем для вивчення анодної поведінки нікелю через слабку адсорбцію їх аніонів.

Зазначимо, що навіть у роботах, у яких вважається, що аніони сульфатної кислоти впливають на анодну поведінку нікелю, до кінетичних схем їх не включають. Так, у роботі [8] сульфат-іони не входять до кінетичного рівняння під тим приводом, що їх концентрація не впливає ні на положення ділянки активного розчинення нікелю, ні на величину потенціалу першого максимуму. На незалежність величин потенціалів максимумів від концентрації сульфат-іонів зазначається також у [14; 15$]$.

\section{Моделювання впливу аніонів сульфатної кислоти на анодні} поляризаційні залежності нікелевого електрода. Для моделювання можливого впливу аніонів сульфатної кислоти на анодну поведінку нікелю в кислих розчинах виходили з кінетичної схеми, яка складається 3 наступних стадій [1]:

$$
\begin{gathered}
\mathrm{Ni} \stackrel{\mathrm{k}_{1}}{\longrightarrow} \mathrm{Ni}^{2+}+2 \overline{\mathrm{e}}, \\
\mathrm{Ni}+\mathrm{OH}^{-} \stackrel{\mathrm{k}_{2}}{\longrightarrow} \mathrm{NiOH}\left(\theta_{1}\right)+\overline{\mathrm{e}} \\
\mathrm{NiOH} \stackrel{\mathrm{k}_{3}}{\longrightarrow} \mathrm{NiOH}^{+}+\overline{\mathrm{e}} \\
\mathrm{NiOH}+\mathrm{OH}^{-} \stackrel{\mathrm{K}_{4}}{\longleftrightarrow} \mathrm{Ni}(\mathrm{OH})_{2}\left(\theta_{2}\right)+\overline{\mathrm{e}}, \\
\mathrm{Ni}(\mathrm{OH})_{2}+\mathrm{Ni} \stackrel{\mathrm{k}_{5}}{\longrightarrow} \mathrm{NiOH}+\mathrm{NiOH}^{+}+\overline{\mathrm{e}} \\
2 \mathrm{Ni}(\mathrm{OH})_{2} \stackrel{\mathrm{K}_{6}}{\longrightarrow} \mathrm{Ni}_{2} \mathrm{O}_{3}\left(\theta_{3}\right)+\mathrm{H}_{2} \mathrm{O}+2 \mathrm{H}^{+}+2 \overline{\mathrm{e}}
\end{gathered}
$$

де $\mathrm{K}_{\mathrm{i}}$ - константи рівноваги стадій (2), (4) i (6); $\mathrm{k}_{\mathrm{i}}$ - кінетичні константи швидкість визначальних стадій (1), (3) і (5); $\theta_{\mathrm{j}}$ - ступені заповнення поверхні.

Шляхів впливу аніонів сульфатної кислоти на анодну поведінку нікелю може бути кілька. Так, згідно 3 концепцією Я. М. Колотиркіна [16], одним із таких шляхів $€$ їх адсорбція на поверхні металу, внаслідок чого аніони $\mathrm{HSO}_{4}^{-}$або $\mathrm{SO}_{4}{ }^{2-}$ конкурують 3 адсорбцією йонів $\mathrm{OH}^{-}$. При цьому відбувається інгібування анодного розчинення металу.

Під час моделювання зазначеного типу впливу обмежились розглядом стадій (2), (4), а також стадії (1), яка відповідає участі в розчиненні нікелю металевої поверхні, вільної від адсорбції, або стадії (3), яка відбувається за участю адсорбованих часток $\mathrm{NiOH}$. До кінетичної схеми анодної поведінки нікелевого електрода додали стадію адсорбції аніонів сульфатної кислоти. При цьому адсорбція сульфат-аніонів відбувається на незайнятій оксигеновмісними сполуками поверхні електрода, а ступінь їх адсорбції або залишається постійною в діапазоні потенціалів анодного розчинення і пасивації нікелю (рис. 1а і 1б, криві 2, 3), або змінюється з величною електродного потенціалу (рис. 1а і 1б, криві 4, 5). 
Окрім розглянутого механізму, також можливе витиснення адсорбованих йонів $\mathrm{OH}^{-}$з поверхні металу аніонами сульфатної кислоти. Зміна ходу і,Е-кривих нікелевого електрода в цьому випадку показана на рис. 1в і 1г.

Згідно з рис. 1, якщо участь йонів в анодних процесах зводиться лише до їх адсорбції на поверхні металу, то на анодних поляризаційних кривих буде спостерігатися зниження величин струмів максимумів. При цьому можливі зміни тафелевського нахилу ділянки активного розчинення металу й величин потенціалів, за яких спостерігаються максимуми струмів.

Згідно 3 літературними джерелами, підвищення вмісту сульфат-іонів у розчинах може привести до збільшення анодних струмів на поляризаційних залежностях нікелевого електрода. Це може відбуватись у тому випадку, якщо аніони сульфатної кислоти або беруть безпосередню участь у стадіях переходу нікелю в розчин, або входять до складу оксигеновмісних плівок. У разі включення аніонів до оксигеновмісних сполук металу їх властивості змінюються, що може вплинути як на кінетику стадій їх розчинення, так і на кінетику стадій подальшого утворення пасивуючих сполук.
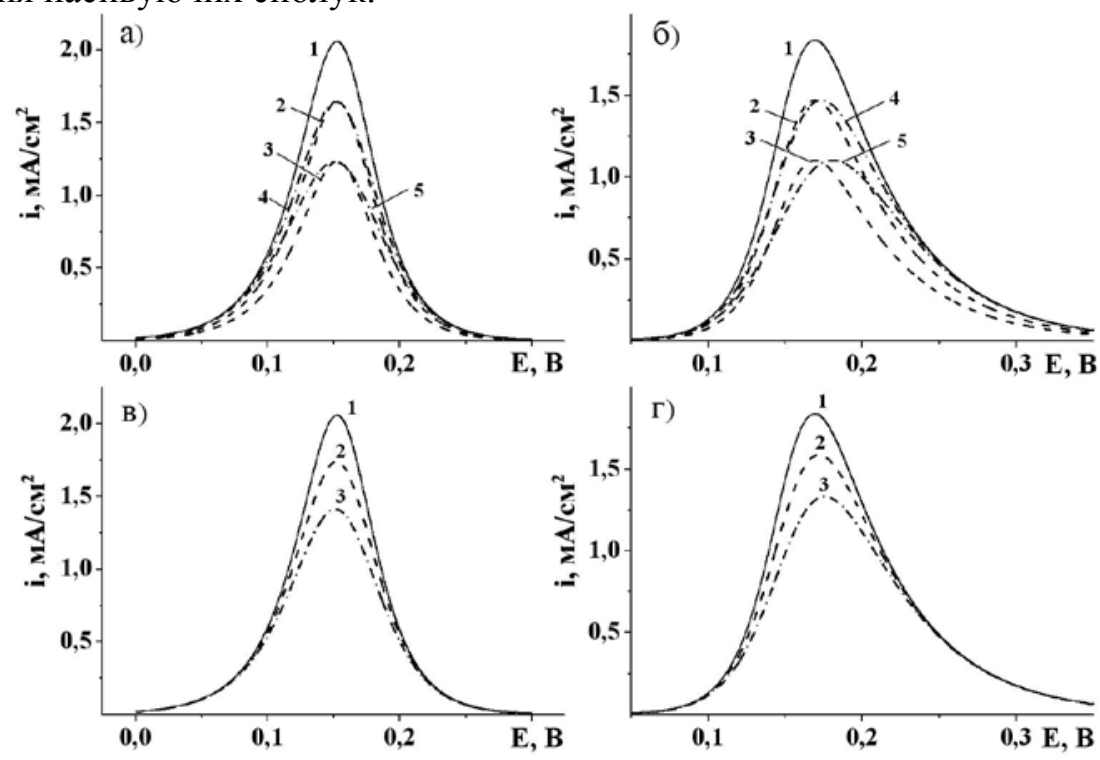

Рис. 1. Модельні анодні поляризаційні криві нікелю, анодна поведінка якого описується рівняннями (1), (2) i (4) (а, в) або (2), (3) i (4) (б, г). Додатково відбувасться адсорбція аніонів сульфатної кислоти зі ступінню заповнення $\theta$ А.

a, б) адсорбція сульфат-іонів відбувається на вільній поверхні електрода. $\theta$ А або не залежить від потенціалу електрода (криві 2,3$)$, або проходить через максимум (криві 4, 5).

в, г) відбувасться витиснення адсорбованих йонів ОН сульфат-аніонами.

Активності сульфат-аніонів $a_{n}\left(n-\right.$ номер кривої), моль/л: $a_{1}=0 ; a_{3,5}>a_{2,4} \cdot$

Під час розрахунків i,E-залежностей, які наведено на рис. 1 i 2 , використовували середні значення параметрів $\mathbf{k}_{\mathrm{i}}, \mathrm{K}_{\mathrm{i}} \mathbf{i} \boldsymbol{\beta}_{\mathrm{i}}$, одержаних під час моделювання анодної поведінки нікелю в [1]

Як видно з розрахункових залежностей, наведених на рис. $2 \mathrm{a}$, якщо до стадій (1), (3) i (5) долучаються додаткові стадії хімічного або електрохімічного розчинення $\mathrm{Ni}$, $\mathrm{NiOH}$ або $\mathrm{Ni}(\mathrm{OH})_{2}$ за участю сульфат-іонів, то, окрім зміни величини струмів максимумів, на анодних поляризаційних залежностях можуть спостерігатися зсув ділянки активного розчинення нікелю i зсув величин потенціалів, за яких спостерігаються максимальні значення струмів. 
Враховуючи, що включення до оксигеновмісних сполук аніонів сульфатної кислоти змінює їх природу, що впливає на термодинамічні характеристики цих сполук і на кінетику реакцій за їх участю, під час моделювання варіювали величини констант швидкості $\left(\mathrm{k}_{\mathrm{i}}\right)$ стадій (3) i (5) і величини констант рівноваги $\left(\mathrm{K}_{\mathrm{i}}\right)$ стадій $(2)$, (4) i (6). Результати розрахунків подані на рис. 26 і 2в. Варіювання констант рівноваги може привести до зміни величин потенціалів максимумів і положення ділянки активного розчинення.

Експериментальна частина. Для перевірки впливу аніонів сульфатної кислоти на анодну поведінку нікелю були зареєстровані поляризаційні залежності в розчинах із вмістом $\mathrm{SO}_{4}{ }^{2-}$ від 0.2 до $1 ., 2$ моль-екв/л. Значення $\mathrm{pH}$ усіх розчинів дорівнювало 1.0. Для приготування розчинів використовували $\mathrm{H}_{2} \mathrm{SO}_{4}$ «ос.ч.», $\mathrm{NaOH}$ «ос.ч.» і бідистильовану воду.

Робочий нікелевий електрод марки Н0 попередньо полірували тонким наждаковим папером, знежирювали віденським вапном i промивали бідистильованою водою. Допоміжним електродом слугувала нікелева пластина, електродом порівняння - насичений хлоросрібний електрод. Електродні потенціали перераховувались відносно стандартного водневого електрода.
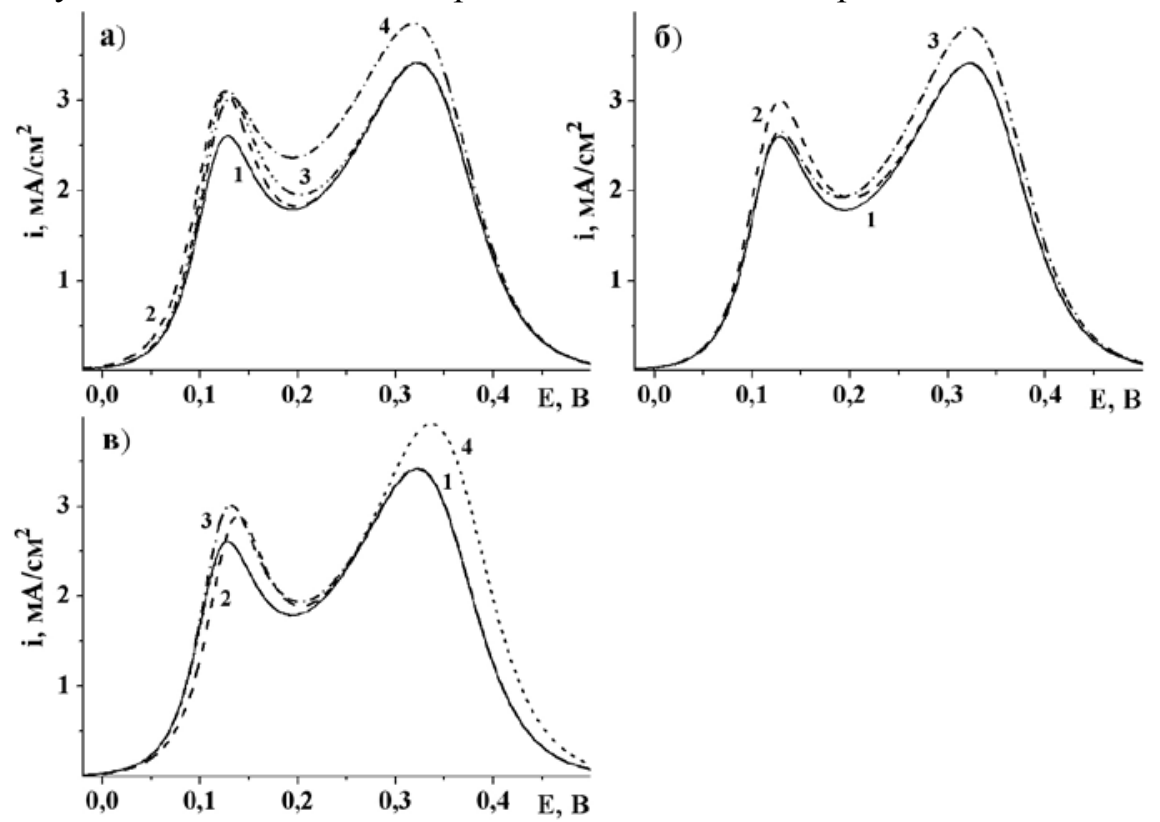

Рис. 2. Моделювання впливу аніонів сульфатної кислоти на анодну поведінку металів. а) до стадій (1), (3) i (5) (крива 1) долучаються стадії: $\mathrm{Ni}+\mathrm{SO}_{4}{ }^{2-} \rightarrow \mathrm{NiSO}_{4}+2 \overline{\mathrm{e}}$ (крива 2); $\mathrm{NiOH}^{+} \mathrm{SO}_{4}{ }^{2-}$

$+\mathrm{H}^{+} \rightarrow \mathrm{NiSO}_{4}+\mathrm{H}_{2} \mathrm{O}+\overline{\mathrm{e}}$ (крива 3); $\mathrm{Ni}(\mathrm{OH})_{2}+\mathrm{SO}_{4}{ }^{2-}+2 \mathrm{H}^{+} \rightarrow \mathrm{NiSO}_{4}+2 \mathrm{H}_{2} \mathrm{O}$ (крива 4).

б) змінюсться кінетика перебігу стадій (3) i (5): $1-\mathrm{k}_{3}=5 \cdot 10^{-8}$ моль $/ \mathrm{cm}^{2} \mathrm{c} ; \mathrm{k}_{5}=6 \cdot 10^{-10} \mathrm{моль} / \mathrm{cm}^{2} \mathrm{c}$; $2-\mathbf{k}_{3}=7 \cdot 10^{-8}$ моль $/ \mathbf{c m}^{2} \mathbf{c} ; \mathbf{k}_{5}=6 \cdot 10^{-10}$ моль $/ \mathrm{cm}^{2} \mathbf{c} ; 3-\mathbf{k}_{3}=5 \cdot 10^{-8}$ моль $/ \mathrm{cm}^{2} \mathbf{c} ; \mathbf{k}_{5}=7 \cdot 10^{-10}$ моль $/ \mathrm{cm}^{2} \mathbf{c}$.

в) змінюються термодинамічні характеристики стадій (2), (4) i (6): $1-K_{2}=3 \cdot 10^{9} ; K_{4}=4 \cdot 10^{12}$;

$K_{6}=1 \cdot 10^{-7} ; 2-K_{2}=1 \cdot 10^{9} ; K_{4}=4 \cdot 10^{12} ; K_{6}=1 \cdot 10^{-7} ; 3-K_{2}=3 \cdot 10^{9} ; K_{4}=3 \cdot 10^{12} ; K_{6}=1 \cdot 10^{-7} ;$

$$
4-K_{2}=3 \cdot 10^{9} ; K_{4}=4 \cdot 10^{12} ; K_{6}=7 \cdot 10^{-8}
$$

Анодні поляризаційні залежності реєстрували зі швидкістю розгортки потенціалу 2 мВ/с 3 використанням потенціостата ПИ-50-1, програматора ПР-8 і потенціометра Н307/1. Розгортку потенціалу починали від величини стаціонарного потенціалу нікелю. Електрохімічна комірка термостатувалась за $25^{\circ} \mathrm{C}$. 
Вплив концентрації аніонів сульфатної кислоти на хід вольтамперних залежностей нікелю в розчинах $\mathrm{H}_{2} \mathrm{SO}_{4}+\mathrm{NaOH}$ показаний на рис. 3. Підвищення вмісту йонів $\mathrm{SO}_{4}^{2-}$ викликає дуже незначне, практично однакове зниження як першого, так і другого максимумів струму (рис. 3а). Величини потенціалів першого максимуму не змінюються, а значення потенціалів другого максимуму дещо зсуваються в додатному напрямку (рис. 3б).

Вплив концентрації сульфат-іонів на хід і,Е-залежностей нікелевого електрода, що спостерігався нами, відрізняється від того, що був виявлений I. К. Маршаковим [8]. Згідно 3 [8], під час підвищення концентрації аніонів сульфатної кислоти спостерігається зменшення величини струму першого максимуму й зростання величини струму другого максимуму. Ці відмінності в знайдених ефектах можна пояснити наступним. Під час проведення експерименту автори роботи [8] для приготування розчинів 3 різним вмістом йонів $\mathrm{SO}_{4}{ }^{2-}$ використовували сіль $\mathrm{Na}_{2} \mathrm{SO}_{4}$ кваліфікації «ч.д.а.» без додаткової перекристалізації. Згідно з технічними характеристиками, ця сіль містить $0.001 \%$ хлоридів. Тобто, в результаті підвищення вмісту йонів $\mathrm{SO}_{4}{ }^{2-}$ від 1 моль-екв/л до 2 моль-екв/л (це відповідає первинному підвищенню вмісту аніонів сульфатної кислоти за $\mathrm{pH}=0,3$ ) у розчин додатково вводиться $10^{-5}$ моль/л йонів $\mathrm{Cl}^{-}$. А судячи 3 даних тієї ж статті [8], в розчинах сульфатної кислоти $310^{-6}$ моль/л $\mathrm{NaCl}$ на вольтамперних залежностях нікелевого електрода спостерігається помітне зниження першого максимуму струму й зростання другого максимуму. 3 подальшим підвищенням концентрації $\mathrm{NaCl}$ цей ефект проявляється ще в більшій мірі. Тобто, вплив йонів $\mathrm{Cl}^{-}$ на поляризаційні характеристики електрода аналогічний впливу, який у [8] пов'язується 3 дією аніонів сульфатної кислоти.

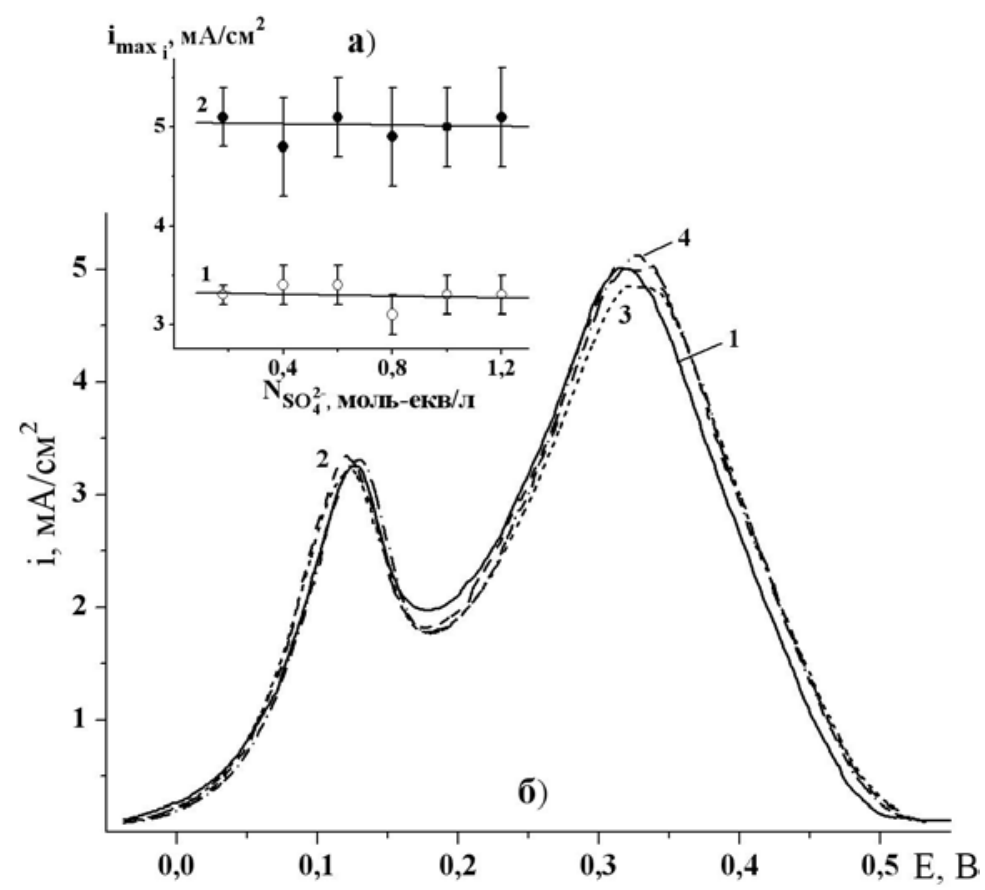

Рис. 3. Вплив концентрації $\mathrm{SO}_{4}{ }^{2-}$-іонів на поляризаційні характеристики нікелевого електрода в розчинах $\mathrm{H}_{2} \mathrm{SO}_{4}+\mathrm{NaOH}$. pH = 1,0. а) залежності першого (1) і другого (2) максимумів струму від концентрації $\mathrm{SO}_{4}{ }^{2-}$; б) вольтамперні залежності в розчинах 3 вмістом $\mathrm{SO}_{4}{ }^{2-}$, моль-екв/л: $1-0.2 ; 2-0.6 ; 3-1.0,4-1.2$ 
На неврахований вплив домішок, присутніх у солі $\mathrm{Na}_{2} \mathrm{SO}_{4}$, свідчить ще й те, що первинне підвищення вмісту йонів $\mathrm{SO}_{4}{ }^{2-}$ в розчинах сульфатної кислоти приводить, як правило, до більш суттєвих змін величин струмів максимумів, ніж його подальше підвищення [8].

Використання для приготування розчинів сульфатної кислоти 3 різним вмістом йонів $\mathrm{SO}_{4}{ }^{2-}$ розчину $\mathrm{NaOH}$ «ос.ч.» дозволяє зменшити концентрацію йонів $\mathrm{Cl}^{-}$, за інших рівних умов, на порядок. Таким чином, одержані нами дані щодо впливу концентрації $\mathrm{SO}_{4}{ }^{2-}$ на анодну поведінку нікелю в розчинах сульфатної кислоти відповідають дійсності більше, ніж одержані в роботі [8].

Зазначимо, що з одержаних експериментальних даних неможливо зробити однозначний висновок про те, що саме йони $\mathrm{SO}_{4}{ }^{2-}$ впливають на анодну поведінку нікелевого електрода. В ході зміни концентрації йонів $\mathrm{SO}_{4}{ }^{2-}$ в розчинах сульфатної кислоти 3 постійним $\mathrm{pH}$ змінюються й інші характеристики розчинів, наприклад, концентрація йонів лужного металу і йонна сила розчину. Тобто, зміни параметрів вольтамперних кривих можуть бути пов'язані також і 3 впливом йонів лужних металів. Можна припустити, що катіони $\mathrm{Na}^{+}$входять до складу пасивуючої плівки. Так, неоднаковий вплив катіонів $\mathrm{Na}^{+}$i $\mathrm{K}^{+}$на анодну поведінку нікелю в лужних розчинах спостерігався авторами роботи [17], що пояснюється включенням катіонів $\mathrm{Na}^{+}$або $\mathrm{K}^{+}$до складу пасивної плівки в якості притивойонів.

Висновки. Концентрація сульфат-іонів у діапазоні від 0.2 до 1.2 моль-екв/л у сульфатних розчинах 3 pH 1.0 практично не впливає на анодні поляризаційні характеристики нікелевого електрода. Виявлений ефект зсуву потенціалів другого максимуму в напрямку більш додатних значень є вкрай незначним i, ймовірно, пояснюється адсорбцією сульфат-аніонів або (й) катіонів лужного металу оксигеновмісними сполуками нікелю. Загалом зміна концентрації аніонів сульфатної кислоти не приводить до змін у механізмі анодного розчинення й пасивації нікелю в кислих розчинах.

\section{Бібліографічні посилання}

1. Петренко Л. В. Моделювання анодної поведінки нікелю в кислих розчинах / Л. В. Петренко, В. І. Коробов // Вісник Дніпропетр. ун-ту. Сер. Хімія. 2012. - Вип. 18. - С. $18-27$.

2. Бунэ Н. Я. К вопросу о пассивации никеля в растворах серной кислоты / Н. Я. Бунэ // Защита металлов. - 1967. - Т. 3, № 1. - С. 50 - 54.

3. Колотыркин Я. М. Влияние природы анионов на кинетику и механизм растворения (коррозии) металлов в растворах электролитов / Я. М. Колотыркин // Защита металлов. - 1967. - № 2. - С. 131 - 144.

4. Burstein G. T. The anodic dissolution of nickel -1 . Perchlorate and fluoride electrolytes / G. T. Burstein, G. A. Wright // Electrochim. Acta. - 1975. - Vol. 20, N 1. P. $95-99$.

5. Zucchi F. Corrosion and corrosion inhibition of nickel in $\mathrm{HClO}_{4}$ solutions using the EQCM technique / F. Zucchi, M. Fonsati, G. Trabanelli // J. Appl. Electrochem. - 1999. - Vol. 29, N 3. - Р. 347 - 353.

6. Исследование кинетики анодного растворения никеля в кислых фосфатных растворах / Р. М. Дворкина, Л. К. Ильина, А. Л. Львов, Л. В. Тюрина // Электрохимия. - 1983. - Т. 19, № 7. - С. 957 - 960.

7. Новаковский В. М. Об особенностях и природе анодного поведения никеля до начала второй пассивации / В. М. Новаковский, Г.Н. Трусов, М. Ф. Фандеева // Защита металлов. - 1969. - Т. 5, № 5. - С. 503 - 509. 
8. Маршаков И. К. Анодное растворение никеля из собственной фазы и фазы интерметаллида $\mathrm{NiZn}$ в кислых сульфатных средах. I. Никель / И. К. Маршаков, Е. Е. Зотова, И. В. Протасова // Защита металлов. - 2004. - Т. 40, № 2. - С. $117-122$.

9. Флорианович Г.М. Об участии анионов в элементарных стадиях электрохимической реакции растворения железа в кислых растворах / Г. М. Флорианович, Л. А. Соколова, Я. М. Колотыркин // Электрохимия. - 1967. T. 3, № 11. - C. $1359-1363$.

10. Real S. G. The characteristics of the potentiodynamic potential/current profiles obtained with the $\mathrm{Ni} / 0.5 \mathrm{~N} \mathrm{H}_{2} \mathrm{SO}_{4}$ interface. A contribution to the mechanism of the electrode process / S. G. Real, J. R. Vilche, A. J. Arvia // Corros. Sci. - 1980. - Vol. 20, N 4. - P. $563-586$.

11. Siejka J. A Study of Passivity Phenomena by Using $\mathrm{O}^{18}$ Tracer Techniques / J. Siejka, C. Cherki // J. Electrochem. Soc. - 1972. - Vol. 119, N 8. - P. 991 - 998.

12. Vilche J. R. Kinetics and mechanism of the nickel electrode - II. Acid solutions containing a high concentration of sulphate and nickel ions / J. R. Vilche, A. J. Arvia // Corros. Sci. - 1978. - Vol.18, N 5. - P. 441 - 463.

13. Schrebler Guzmán R. S. The kinetics and mechanism of the nickel electrode III. The potentiodynamic response of nickel electrodes in alkaline solutions in the potential region of $\mathrm{Ni}(\mathrm{OH})_{2}$ formation / R. S. Schrebler Guzmán, J. R. Vilche, A. J. Arvía // Corros. Sci. - Vol. 18. - P. 765 - 778.

14. Лоповок Г. Г. Влияние сульфат ионов на анодное поведение никеля / Г. Г. Лоповок, Я. М. Колотыркин, Л. А. Медведева // Защита металлов. - 1966. Т. 2. № 5. - С. $527-532$.

15. Новосельский И. М. К кинетической теории пассивации анодно растворяющихся металлов. XV. Свойства стационарных вольт-амперных кривых, описывающих механизм ингибирования электродной реакции на свободной поверхности двумя адсорбированными продуктами последовательной реакции электрохимической адсорбции / И. М. Новосельский, М. Г. Хакимов // Электрохимия. - 1974. - Т. 10, № 1. - С. 86 - 91.

16. Колотыркин Я. М. О механизме влияния анионов раствора на кинетику растворения металлов. Роль взаимодействия / Я. М. Колотыркин, Ю. А. Попов, Ю. В. Алексеев // Электрохимия. - 1973. - Т. 9. № 5. - С. 624 - 629.

17. Grdeń M. A quartz crystal microbalance study on a metallic nickel electrode / M. Grdeń, K. Klimek, A. Czerwiński // J. Solid Stat. Eletrochem. - 2004. - Vol. 8. P. $390-397$.

\section{V. Petrenko, ${ }^{1}$ Viktor I. Korobov, ${ }^{1, *}$ V. F. Ochkov ${ }^{2}$ \\ ${ }^{1}$ Oles Honchar Dnipropetrovsk National University, 72, Gagarin Ave., Dnipropetrovsk 49010, Ukraine \\ ${ }^{2}$ National Research University «Moscow Power Engineering Institute», 14, Krasnokazarmennaya str., Moscow 111250, Russia \\ INFLUENCE OF SULFURIC ACID ANIONS ON NICKEL ANODIC BEHAVIOR}

The anions $\mathrm{HSO}_{4}{ }^{-}$and $\mathrm{SO}_{4}{ }^{2-}$ can be involved to the process of iron's subgroup metals anodic dissolution and passivation in sulfuric acid solutions. The possible effect sulfuric acid on the anodic behavior of nickel in acidic solutions was analyzed with mathematic modeling application. Our results have shown a decrease of maximum current on the anode polarization curve in the case of sulfate anions adsorption on the nickel surface. In this case the slope of Tafel plot of nickel active dissolution and the potentials of maximum currents may change. Maximum currents increasing have been occur 
in the cases as a direct involvement of sulfuric acid in the dissolution stage of nickel as inclusion of anions into the oxygen-containing films. It was found that anions of sulfuric acid practically didn't influence on the anodic polarization curve of nickel electrode in the range of $\mathrm{SO}_{4}{ }^{2-}$ anion concentration from 0,2 to $1,2 \mathrm{Eq} / \mathrm{L}(\mathrm{pH}=1,0)$. These data allows to argue that the sulfate anions do not affect on the general mechanism of anodic dissolution and passivation of nickel.

Key words: nickel; acidic solution; anodic dissolution; passivation; sulfate anions; modeling.

Л. В. Петренко, ${ }^{1}$ Виктор И. Коробов, ${ }^{1}$ В. Ф. Очков ${ }^{2}$

${ }^{1}$ Днепропет ровский национальный университ ет имени Олеся Гончара, пр. Гагарина, 72, Днепропет ровск 49010, Украина

${ }^{2}$ Национальный исследоват ельский университ ет «Московский энергет ический инст ит ут », ул. Красноказарменная, 14, Москва 11125, Россия

\section{ВЛИЯНИЕ АНИОНОВ СЕРНОЙ КИСЛОТЫ НА АНОДНОЕ ПОВЕДЕНИЕ НИКЕЛЯ}

В стадиях анодного растворения и пассивации металлов подгруппы железа в растворах серной кислоты могут принимать участие анионы $\mathrm{HSO}_{4}{ }^{-}$и $\mathrm{SO}_{4}{ }^{2-}$. С применением математического моделирования проанализировано возможное влияние анионов серной кислоты на анодное поведение никеля в кислых растворах. Показано, что в случае адсорбции сульфат-анионов на поверхности никеля на анодных поляризационных зависимостях наблюдается снижение максимальных значений токов. При этом могут наблюдаться изменения величины тафелевского наклона участка активного растворения никеля и значений потенциалов максимумов токов. Увеличение максимальных значений анодных токов будет наблюдаться в случае непосредственного участия анионов серной кислоты в стадиях растворения никеля, а также в случае включения анионов в состав кислородсодержащих пленок. Экспериментально установлено, что ход анодных поляризационных зависимостей никелевого электрода практически не зависит от содержания сульфат-анионов в диапазоне концентраций $\mathrm{SO}_{4}^{2-}$ от 0,2 до 1,2 моль-экв/л (pH = 1,0). Этот факт позволяет утверждать, что сульфат-анионы не влияют на общий механизм анодного растворения и пассивации никеля.

Ключевые слова: никель; кислая среда; анодное растворение; пассивация; сульфат-анионы; моделирование.

\section{References}

1. Petrenko, L. V., Korobov, V. I. Simulation anodic behavior of nickel in acidic solutions. Visn. Dnipropetr. Univ.: Khim., 2012, no. 18, p. 18-27.

2. Bune, N. Ya. On the passivation of nickel in sulfuric acid solutions. Zaschita metallov, 1967, no. 1. p. 50-54.

3. Kolotyirkin, Ya. M. Influence of the nature of anions on the kinetics and mechanism of dissolution (corrosion) of metals in electrolyte solutions Zaschita metallov, 1967, no. 2, p. 131-144.

4. Burstein, G. T., Wright, G. A. The anodic dissolution of nickel -1 . Perchlorate and fluoride electrolytes. Electrochim. Acta, 1975, no. 1, p. 95-99.

5. Zucchi, F., Fonsati, M., Trabanelli, G. Corrosion and corrosion inhibition of nickel in $\mathrm{HClO}_{4}$ solutions using the EQCM technique. J. Appl. Electrochem., 1999, no. 3, p. 347-353.

6. Dvorkina, R. M., Ilina, L. K., Lvov, A. L, Tyurina, L. V. Investigation of the kinetics of anodic dissolution of nickel in acidic phosphate solutions. Elektrohimiya, 1983, no. 7, p. 957-960.

7. Novakovskiy, V. M., Trusov, G. N., Fandeeva, M. F. On the characteristics and nature of the anodic behavior of nickel before the second passivation. Zaschita metallov, 1969, no. 5, p. 503-509.

8. Marshakov, I. K., Zotova, E. E., Protasova, I. V. Anodic dissolution of nickel from its own phase and phase NiZn intermetallic compound in acid sulfate environments. I. Nickel. Zaschita metallov, 2004, no. 2, p. 117-122. 
9. Florianovich, G. M., Sokolova, L. A., Kolotyirkin, Ya. M. On participation anions in elementary steps of the electrochemical reaction of iron dissolution in acidic. Elektrohimiya, 1967, no. 11, p. 1359-1363.

10. Real, S. G., Vilche, J. R., Arvia A. J. The characteristics of the potentiodynamic potential/current profiles obtained with the $\mathrm{Ni} / 0.5 \mathrm{~N} \mathrm{H}_{2} \mathrm{SO}_{4}$ interface. A contribution to the mechanism of the electrode process. Corros. Sci., 1980, no. 4, p. 563-586.

11. Siejka, J., Cherki, C. Study of Passivity Phenomena by Using $\mathrm{O}^{18}$ Tracer Techniques. J. Electrochem. Soc., 1972, no. 8, p. 991-998.

12. Vilche, J. R., Arvia, A. J. Kinetics and mechanism of the nickel electrode - II. Acid solutions containing a high concentration of sulphate and nickel ions. Corros. Sci., 1978, no. 5, p. 441-463.

13. Schrebler Guzmán, R. S., Vilche, J. R., Arvía, A. J. The kinetics and mechanism of the nickel electrode - III. The potentiodynamic response of nickel electrodes in alkaline solutions in the potential region of $\mathrm{Ni}(\mathrm{OH})_{2}$ formation. Corros. Sci., vol. 18, p. 765-778.

14. Lopovok, G. G., Kolotyirkin, Ya. M., Medvedeva, L. A. Effect of sulfate ions on the anodic behavior of nickel. Zaschita metallov, 1966, no. 5, p. 527-532.

15. Novoselskiy, I. M., Hakimov, M. G. Kinetic theory of anode passivation dissolving metals. XV. Properties of the steady current-voltage curves describing the mechanism of inhibition of the electrode reaction at the free surface in two consecutive reaction products adsorbed electrochemical adsorption. Elektrohimiya, 1974, no. 1, p. 86-91.

16. Kolotyirkin, Ya. M., Popov, Yu. A., Alekseev, Yu. V. On the mechanism of the influence of anions on the kinetics of dissolution solution metals. Role of the solvents. Elektrohimiya, 1973, no. 5, p. 624-629.

17. Grdeń, M., Klimek, K., Czerwiński, A. A quartz crystal microbalance study on a metallic nickel electrode. J. Solid Stat. Eletrochem., 2004, vol. 8, p. 390-397.

Надійила до редколегії 13.03.13 